\title{
Analisis Penerapan Anggaran Berbasis Kinerja dengan Konsep Money Follow Program Dalam Perencanaan dan Penganggaran Kota Padang
}

\author{
SILVIA NINGSIH, AFRIDIAN WIRAHADI, AMY FONTANELLA \\ ${ }^{1}$ Program Studi Diploma IV Akuntansi Jurusan Akuntansi, Politeknik Negeri Padang \\ Email: silvianingsih84@gmail.com
}

\begin{abstract}
ABSTRAK
Anggaran berbasis kinerja merupakan perencanaan kinerja tahunan secara terintegrasi yang menunjukkan hubungan antara tingkat pendanaan dan hasil yang diinginkan dari program tersebut, sedangkan konsep money follow program merupakan pendekatan penganggaran yang lebih fokus kepada program/kegiatan yang terkait langsung dengan prioritas daerah serta memberikan dampak langsung bagi masyarakat. Penelitian ini bertujuan untuk mengevaluasi penerapan anggaran berbasis kinerja dengan konsep money follow program dalam perencanaan dan penganggaran Pemerintah Kota Padang. Penelitian menggunakan pendekatan analisis deskriptif kualitatif dengan data anggaran tahun 2017-2019. Indikator yang digunakan dalam mengevaluasi anggaran berbasis kinerja yakni adanya penetapan strategi organisasi (visi, misi, tujuan, dan sasaran), adanya penetapan aktifitas, dan evaluasi terhadap kinerja periode sebelumnya. Hasil penelitian menunjukkan bahwa Pemerintah Kota Padang telah menerapkan anggaran berbasis kinerja dengan konsep money follow program dalam kegiatan perencanaan dan penganggaran. Hal ini dapat dilihat dari adanya penetapan strategi organisasi (visi, misi, tujuan, dan sasaran), adanya penetapan aktifitas, dan adanya evaluasi terhadap kinerja periode sebelumnya.
\end{abstract}

Kata Kunci: Anggaran Berbasis Kinerja, Money Follow Program, Perencanaan dan Penganggaran

\begin{abstract}
Performance-based budgeting is an integrated annual performance planning that shows the relationship between funding levels and desired outcomes of the program, while the concept of money follow program is a budgeting approach that focuses more on programs / activities that are directly related to regional priorities and have a direct impact on the community. This study aims to evaluate the performance-based budget implementation with the concept of money follow program in the planning and budgeting of the Padang City Government. The study used a qualitative descriptive analysis approach with 2017-2019 budget data. Indicators used in evaluating performance-based budgets are the establishment of organizational strategies (vision, mission, goals, and objectives), the establishment of activities, and evaluation of the performance of the previous period. The results showed that the Padang City Government had implemented a performance-based budget with the concept of money follow program in planning and budgeting activities. This can be seen from the determination of organizational strategy (vision, mission, goals and objectives), the establishment of activities, and the evaluation of the performance of the previous period.
\end{abstract}

Keywords: Performance Based Budgeting, Money Follow Program, Planning and Budgeting

\section{PENDAHULUAN}

Otonomi daerah menciptakan ruang gerak yang lebih bebas bagi pemerintah daerah dalam membuat kebijakan dan peraturan daerah. Pelaksanaan otonomi daerah di Indonesia yang didasarkan pada Undang-Undang (UU) Nomor 23 Tahun 2014 tentang Pemerintah Daerah. UU Nomor 23 Tahun 2014 ini merupakan landasan bagi 
Pemerintah Daerah dalam menjalankan pemerintahan di daerahnya. Pelaksanaan otonomi daerah dilakukan dengan melibatkan pihak-pihak terkait yang sesuai dengan pemahaman dan kebutuhan masyarakat didaerah tersebut, tidak terkecuali dengan pembangunan di berbagai sektor. Pelaksanaan otonomi daerah mewajibkan pemerintah daerah untuk melakukan pembangunan di daerah sesuai dengan kebutuhannya.

Menurut Peraturan Menteri Dalam Negeri (Permendagri) No. 86 Tahun 2017, pembangunan daerah merupakan usaha yang sistematik untuk pemanfaatan sumber daya yang dimiliki Daerah serta meningkatkan akses dan kualitas pelayanan publik dan daya saing Daerah sesuai dengan urusan pemerintahan yang menjadi kewenangannya. Pembangunan daerah ini bertujuan untuk meningkatkan kesejahteraan masyarakat yang ada di daerah tersebut sebagaimana yang diamanatkan dalam UU No. 23 Tahun 2014 pasan 25 dan 26. Untuk melaksanakan kegiatan pembangunan pemerintah memiliki kewenangan untuk membelanjakan dana yang berkaitan dengan pembangunan daerah. Sehingga dalam proses pembangunan tersebut dibutuhkan pengelolaan keuangan daerah yang efektif dan efisien.

Pengelolaan keuangan daerah merupakan keseluruhan kegiatan yang meliputi perencanaan, pelaksanaan, penatausahaan, pelaporan, pertanggungjawaban, dan pengawasan keuangan daerah (Peraturan Pemerintah No. 58 Tahun 2005). Dalam melaksanakan pengelolaan keuangan daerah pemerintah daerah harus mengacu kepada peraturan-peraturan yang mengatur tentang pengelolaan keuangan daerah, peraturan tersebut salah satunya yaitu Peraturan Menteri Dalam Negeri (Permendagri) Nomor 13 Tahun 2006 serta Peraturan Pemerintah (PP) No. 58 Tahun 2005. Salah satu aspek penting dalam pengelolaan keuangan daerah yaitu aspek perencanaan karena kegagalan dalam merencanakan sebuah pengelolaan sama halnya dengan merencanakan sebuah kegagalan sehingga tidak tercapainya pengelolaan keuangan yang efektif.

Selain aspek pengelolaan keuangan, tahapan perencanaan merupakan suatu proses untuk menentukan tindakan masa depan yang tepat melalui urutan pilihan dengan memperhitungkan sumber daya yang tersedia (Bastian, 2006). Perencanaan pembangunan daerah disusun untuk menjamin keterkaitan dan konsitensi antara perencanaan, penganggaran, pelaksanaan, dan pengawasan. Perencanaan pembangunan terdiri dari perencanaan pembangunan jangka panjang daerah (RPJPD), perencanaan pembangunan jangka menengah daerah (RPJMD), dan perencanaan pembangunan tahunan daerah yang biasa disebut dengan Rencana Kerja Pemerintah Daerah (RKPD) (Undang-Undang No. 25 Tahun 2004). Dalam melakukan perencanaan, proses penting yang perlu diperhatikan pemerintah daerah yaitu penyusunan anggaran. Karena perencanaan pembangunan ini harus didukung oleh ketersediaan dana yang cukup agar perencanaan tersebut dapat dilakukan.

Saat ini penyusunan penganggaran pemerintah daerah dikenal dengan istilah Anggaran Berbasis Kinerja (performance based budgeting). Anggaran berbasis kinerja (ABK) merupakan perencanaan kinerja tahunan secara terintegrasi yang menunjukkan hubungan antara tingkat pendanaan program dan hasil yang diinginkan dari program tersebut (Bastian, 2006). Anggaran dengan pendekatan kinerja adalah system penganggaran yang mengutamakan pencapaian upaya hasil kerja atau output dari perencanaan alokasi biaya atau input yang ditetapkan. Dalam anggaran berbasis kinerja harus memuat standar pelayanan yang diharapkan dan perkiraan biaya satuan komponen kegiatan yang bersangkutan. Dalam proses 
pelaksanaan anggaran berbasis kinerja, pendanaan harus merujuk kepada kebijakan pemerintah pusat. Salah satu kebijakan pemerintah pusat mulai tahun 2014 terkait dengan anggaran berbasis kinerja yaitu konsep money follow program.

Money follow program merupakan pendekatan pengganggaran yang lebih focus pada program/kegiatan yang terkait langsung dengan prioritas nasional serta memberikan dampak langsung bagi masyarakat. Money follow program diimplementasikan dengan cara mengamankan alokasi pada prioritas, realokasi dari program kegiatan yang telah cukup mendapat penekanan pada tahun-tahun sebelumnya, dan efisiensi program/kegiatan nonprioritas. Penyusunan anggaran berbasis kinerja dengan menggunakan pendekatan money follow program merupakan pendekatan yang baru diterapkan oleh pemerintah daerah kabupaten/kota di Indonesia, termasuk pemerintah daerah Kota Padang. Selama ini kegiatan perencanaan penganggaran didasarkan pada pendekatan money follow fuction. Pendekatan money follow fuction lebih menegaskan bahwa pengalokasian anggaran harus berdasarkan fungsi masing-masing unit dalam organisasi pemerintah. Sedangkan pendekatan money follow program penganggaran berdasarkan pada bobot program/kegiatan sesuai dengan tujuan yang ditetapkan oleh pemerintah.

Mengingat pendekatan ini baru diterapkan dan keterbatasan sumber daya yang dimiliki oleh pemerintah daerah untuk menerapkan pendekatan tersebut maka sangat penting dilakukan penelitian yang terkait dengan penerapan pendekatan money follow program dalam proses perencanaan dan penganggaran di pemerintah daerah kabupaten/kota. Kota Padang dipilih sebagai salah satu objek penelitian ini karena Kota Padang merupakan salah satu kota yang memiliki anggaran cukup besar, serta Kota Padang memang sudah merencanakan untuk menerapkan penyusunan anggaran berbasis kinerja dengan pendekatan money follow program. Kota Padang merupakan ibukota dari Provinsi Sumatera Barat. Visi Kota Padang berdasarkan RPJPD Kota Padang 2005-2025 yakni “Terwujudnya masyarakat madani yang berbasis industri, perdagangan dan jasa yang unggul dan berdaya saing tinggi dalam kehidupan perkotaan yang tertib dan teratur".

Dalam penetapan visi tersebut diperlukan perencanaan dan penganggaran yang baik dalam pembangunan. Dalam rangka meningkatkan kesejahteraan masyarakat Pemerintah Daerah Kota Padang selalu berupaya mencapai tujuan tersebut dengan tidak meninggalkan tujuan yang akan dicapai dimasa datang. Upaya tersebut sematamata ditujukan untuk mewujudkan kondisi daerah dan rakyatnya dalam kondisi lebih baik dibandingkan masa lalu dan sekarang, salah satunya yaitu dengan adanya pembangunan yang berkesinambungan. Pembangunan yang berkesinambungan akan meningkatkan kebutuhan akan dana. Berdasarkan fenomena tersebut penulis tertarik melakukan penelitian dengan judul "Analisis Perencanaan Anggaran Berbasis Kinerja dengan Konsep Money Follow Program dalam Perencanaan Penganggaran Kota Padang".

\section{KAJIAN TEORI \\ ANGGARAN BERBASIS KINERJA}

\section{Pengertian Anggaran Berbasis Kinerja}

Menurut Governmental Accounting Standards Board (GASB), defenisi anggaran (budget) adalah rencana operasi keuangan yang mencakup estimasi pengeluaran yang diusulkan, dan sumber pendapatan yang diharapkan untuk membiayainya dalam periode waktu tertentu. Sedangkan menurut Bastian (2016), anggaran merupakan proses menilai perencanaan pendapatan dan belanja dalam suatu periode 
tertentu. Berdasarkan pengertian di atas, maka dapat ditarik kesimpulan bahwa anggaran merupakan rencana keuangan yang disusun dan digunakan selama periode tertentu.

Menurut PP No. 58 Tahun 2005 tentang Pengelolaan Keuangan Daerah, kinerja adalah keluaran/hasil dari kegiatan/program yang akan atau telah dicapai sehubungan dengan penggunaan anggaran dengan kuantitas dan kualitas yang terukur. Menurut Nanda dan Darwanis (2016), kinerja merupakan gambaran mengenai tingkat pencapaian pelaksanaan suatu kegiatan/program, kebijakan dalam mewujudkan sasaran, tujuan, serta visi dan misi organisasi yang tertuang dalam rencana strategis suatu organisasi. Sedangkan pengukuran kinerja merupakan suatu proses penilaian kemajuan pekerjaan terhadap tujuan dan sasaran yang telah ditentukan sebelumnya termasuk informasi atas efisiensi penggunaan sumber daya dalam menghasilkan barang/jasa, kualitas barang/jasa, hasil kegiatan dibandingkan dengan maksud yang diinginkan. Dari pengertian diatas, dapat ditarik kesimpulan bahwa kinerja merupakan prestasi kerja yang dicapai dalam melaksanakan suatu kegiatan.

Anggaran berbasis kinerja pada dasarnya merupakan suatu anggaran yang berfokus pada hasil yang akan dicapai. Menurut Direktorat Pengawasan dan Penyelenggaraan Keuangan Daerah (2005), anggaran berbasis kinerja merupakan metode penganggaran bagi manajemen untuk mengaitkan setiap pendanaan yang dituangkan dalam kegiatan-kegiatan dengan keluaran dan hasil yang diharapkan termasuk efisiensi dalam pencapaian hasil dari keluaran tersebut. Menurut Nanda dan Darwanis (2016), anggaran berbasis kinerja merupakan sistem penganggaran bagi manajemen untuk mengaitkan setiap pendanaan yang dituangkan dalam kegiatan-kegiatan dengan ouput dan outcome yang diharapkan termasuk efisiensi dalam pencapain outcome dari output tersebut. Output dan outcome tersebut dituangkan didalam target kinerja yang telah dibuat pada setiap unit kinerja. Dalam Undang-Undang Nomor 17 Tahun 2003, anggaran berbasis kinerja adalah sistem penyusunan anggaran berdasarkan pada kinerja atau prestasi kerja yang akan dicapai.

\section{Prinsip dan Tujuan Anggaran Berbasis Kinerja}

Dalam menetapkan anggaran berbasis kinerja terdapat beberapa prinsip yang harus diperhatikan. Menurut Pedoman Penyusunan Anggaran Berbasis Kinerja (2005), prinsip dari anggaran berbasis kinerja adalah sebagai berikut:

1. Transparansi dan Akuntabilitas Anggaran

APBD harus dapat menyajikan informasi yang jelas mengenai tujuan, sasaran, hasil, dan manfaat yang diperoleh masyarakat dari suatu kegiatan atau proyek yang dianggarkan. Anggota masyarakat memiliki hak dan akses yang sama untuk mengetahui proses anggaran karena menyangkut aspirasi dan kepentingan masyarakat. Masyarakat juga berhak untuk menuntut pertanggungjawaban atas rencana ataupun pelaksanaan anggaran tersebut.

2. Disiplin Anggaran

Pendapatan yang direncanakan merupakan perkiraan yang terukur secara masuk akal yang nantinya dapat dicapai untuk setiap sumber pendapatan, sedangkan belanja yang dianggarkan pada setiap pos anggaran merupakan batas tertinggi pengeluaran belanja. Penggunaan dana pada setiap pos anggaran harus sesuai dengan kegiatan yang direncanakan. 
3. Keadilan Anggaran

Pemerintah daerah wajib mengalokasikan penggunaan anggarannya dengan adil agar dapat dinikmati oleh seluruh komponen masyarakat tanpa adanya diskriminasi didalam pemberian pelayanan.

4. Efektifitas dan Efisiensi Anggaran

Penyusunan anggaran harus dilakukan dengan azas efisiensi, tepat waktu dan tepat guna serta dapat dipertanggungjawabkan. Dana yang telah disediakan harus dapat dimanfaatkan dengan sebaik-baiknya agar menghasilkan peningkatan dan kesejahteraan yang optimal untuk kepentingan stakeholders.

5. Disusun dengan Pendekatan Kinerja

Penyusunan anggaran dengan pendekatan kinerja mengutamakan pada pencapaian hasil kerja dari perencanaan alokasi biaya yang telah ditetapkan. Pencapaian hasil kerja tersebut harus sama atau lebih besar daripada biaya yang telah ditetapkan sebelumnya.

Berdasarkan prinsip-prinsip tersebut diatas maka tujuan dari penerapan anggaran berbasis kinerja adalah sebagai berikut:

1. Menunjukkan keterkaitan antara pendanaan dan prestasi kinerja yang akan dicapai (directly linkages between performance and budget).

2. Meningkatkan efisiensi dan transparansi dalam hal pelaksanaan pengelolaan anggaran (operational efficiency).

3. Meningkatkan fleksibilitas dan akuntabilitas unit dalam melaksanakan tugas dan pengelolaan anggaran (more flexibility and accountability).

\section{Tahapan Penyusunan Anggaran Berbasis Kinerja}

Menurut Nordiawan (2006), tahap-tahap penyusunan anggaran berbasis kinerja adalah sebagai berikut:

1. Penetapan Strategi Organisasi (Visi dan Misi)

Penetapan strategi organisasi merupakan cara pandang jauh kedepan yang memberikan gambaran tentang suatu kondisi yang akan dicapai oleh sebuah organisasi. Dari sudut pandang lain, visi dan misi organisasi harus dapat:

a. Mencerminkan apa yang ingin dicapai

b. Memberikan arah dan focus strategi yang jelas

c. Menjadi perekat dan menyatukan berbagai gagasan strategi

d. Memiliki orientasi masa depan

e. Menumbuhkan seluruh unsur organisasi

f. Menjamin kesinambungan kepemimpinan organisasi

2. Pembuatan Tujuan

Tujuan dalam hal ini adalah sesuatu yang akan dicapai dalam kurun waktu satu tahun atau yang sering diistilahkan dengan tujuan operasional. Karena tujuan operasional merupakan turunan dari visi dan misi organisasi, tujuan operasional seharusnya menjadi dasar untuk alokasi sumber daya yang dimiliki, mengelola aktivitas harian, serta permberian penghargaan dan hukuman.

3. Penetapan Aktifitas

Penetapan aktifitas merupakan hal yang mendasar dalam penyusunan anggaran, karena penetapan aktifitas dipilih berdasarkan strategi organisasi dan tujuan yang telah ditetapkan. 
4. Evaluasi dan Pengambilan Keputusan

Evaluasi dan pengambilan keputusan dapat dilakukan dengan menggunakan standar buku yang telah ditetapkan oleh suatu organisasi atau dengan memberikan kebebasan pada masing-masing unit kerja untuk membuat kriteria-kriteria dalam menentukan peringkatnya.

\section{PENDEKATAN MONEY FOLLOW PROGRAM}

Dalam penyusunan rencana kerja dan anggaran dalam pemerintahan disusun berdasarkan prestasi kerja yang akan dicapai. Hal ini diamanatkan dalam UndangUndang Nomor 17 Tahun 2003 tentang Keuangan Negara dimana dalam penyusunan RAPBN dan RKA-K/L, pemerintah wajib menerapkan anggaran berbasis kinerja. Pengalokasian anggaran dengan pendekatan fungsi atau yang dikenal dengan money follow function, sebagai salah satu prinsip anggaran berbasis kinerja merupakan pendekatan yang strategis dalam menjaga efektivitas dan efisiensi dalam penggunaan anggaran. Namun Kontan (2016, September) menyebutkan bahwa pemerintah akan mempertajam program prioritas pembangunan pada 2017 dengan menggunakan sistem money follow program. Pengalokasi anggaran tidak lagi berdasarkan pada fungsi, melainkan berdasarkan program prioritas nasional.

Dalam Majalah Keuangan Publik (2016) disebutkan bahwa ada dua alasan yang dikemukakan mengapa money follow fuction dianggap tidak tepat, yaitu:

1. Dianggap menjadi penyebab terjadinya inefisiensi dalam penganggaran, karena melalui pendekatan ini semua fungsi-fungsi pemerintahan harus didanai walaupun tidak semuanya termasuk dalam program-program prioritas, metode yang digunakan adalah tambah/kurang sebesar persentase perubahan pagu berdasarkan data tahun sebelumnya

2. Melemahkan koordinasi antar sektor-sektor pembangunan, karena banyaknya program/ kegiatan yang jalan sendiri-sendiri (tidak terkoordinasi satu sama lainnya).

Konsep money follow function pada prinsipnya menegaskan bahwa pengalokasian anggaran harus berdasarkan fungsi masing-masing unit dalam organisasi pemerintah. Dengan tujuan untuk membangun konsep penganggaran yang efektif, efisien, dan menjaga kesinambungan fiskal melalui upaya peningkatan kualitas belanja (quality spending). Dalam konsep money follow function tidak serta merta membagi anggaran pada semua unit/organisasi secara merata, tetapi tetap ada proses penilaian (assessment) terhadap usul sebuah program/ kegiatan yang akan diusulkan oleh setiap unit/organisasi. Penilaian tersebut menyangkut apakah program/ kegiatan yang diusulkan termasuk dalam proses prioritas yang harus didanai atau tidak serta bagaimana kontribusi dan dampaknya terhadap pelaksanaan pembangunan.

Sedangkan dalam konsep money follow program ditegaskan bahwa perlunya pendekatan penganggaran yang berdasarkan pada bobot program/kegiatan sesuai dengan tujuan yang ditetapkan oleh pemerintah, dimana program/kegiatan dikatakan memiliki bobot yang tinggi jika memberi manfaat yang besar kepada rakyat. Melalui pendekatan ini diharapkan : (1) adanya skala prioritas alokasi yang tinggi pada program-program yang memberikan manfaat yang besar kepada masyarakat; (2) program dan kegiatan yang akan didanai lebih tegas dan jelas, sehingga jelas sasaran yang akan dicapai lebih optimal dan teratur; (3) mendorong terciptanya efisiensi melalui koordinasi yang jelas antarprogram dan kegiatan. Dalam konsep money follow program juga ditegaskan bahwa adanya penilaian atas program- 
program yang akan diajukan. Hal ini bertujuan untuk memberikan menentukan program mana yang dapat memberikan manfaat besar untuk masyarakat.

Sehingga dapat disimpulkan bahwa perbedaan antara konsep money follow fuction dengan money follow program adalah sebagai berikut:

Tabel 1. Perbedaan Pendekatan Money Follow Fuction dan Money Follow Program

\begin{tabular}{|l|l|l|l|}
\hline No. & Uraian & Money Follow Function & Money Follow Program \\
\hline 1. & Perencanaan Alokasi & $\begin{array}{l}\text { Dimulai dari indetifikasi } \\
\text { kebutuhan unit/K/L } \\
\text { - Pelaksanaan tusi } \\
\text { - Dukungan pada prioritas }\end{array}$ & $\begin{array}{l}\text { Dimulai dari penentuan } \\
\text { program prioritas untuk } \\
\text { diturunkan pada unit/K/L yang } \\
\text { terkait }\end{array}$ \\
\hline 2. & Realokasi Anggaran & $\begin{array}{l}\text { Kaku karena sekat organisasi } \\
\text { dengan sasarannya masing- } \\
\text { masing }\end{array}$ & $\begin{array}{l}\text { Lebih mudah dilakukan karena } \\
\text { di arahkan untuk pencapaian } \\
\text { sasaran program }\end{array}$ \\
\hline 3. & Pelaksanaan Anggaran & $\begin{array}{l}\text { Penanggung jawab ada di } \\
\text { masing-masing unit } \\
\text { Berpotensi tidak terintegrasi } \\
\text { satu sama lainnya (kebijkan, } \\
\text { spasial maupun urutan } \\
\text { pembangunan) }\end{array}$ & $\begin{array}{l}\text { Kabijakan lebih mudah } \\
\text { dintegrasikan karena control } \\
\text { pada program prioritas } \\
\text { Dapat ditumjuk penanggung } \\
\text { jawab kegiatan yang bersifat } \\
\text { lintas unit }\end{array}$ \\
\hline
\end{tabular}

\section{METODE PENELITIAN JENIS PENELITIAN}

Penelitian ini menggunakan pendekatan analisis deskriptif kualitatif dengan mengumpulkan data bukan berupa angka-angka, melainkan data yang berasal dari publikasi dokumen resmi lainnya. Tujuan dari penelitian kualitatif ini adalah untuk menggambarkan keadaan yang sebenarnya dari objek penelitian.

\section{LOKASI DAN WAKTU PENELITIAN}

Lokasi penelitian merupakan tempat di mana penelitian dilakukan. Dalam penelitian ini peneliti melakukan penelitian di Kota Padang. Pemilihan lokasi ini karena Kota Padang merupakan ibu kota Provinsi Sumatera Barat dan salah satu yang memiliki nilai anggaran untuk kinerja setiap tahunnya tergolong besar serta Pemerintah Kota Padang sudah merencanakan untuk penetapan pendekatan money follow program untuk tahun anggaran 2017. Oleh karena itu lah penelitian mengenai analisis penerapan anggaran berbasis kinerja dan money follow program dilakukan di Kota Padang. Adapun waktu penelitian dilakukan dari Juli sampai Agustus 2018.

\section{METODE PENGUMPULAN DATA}

Moleong (2014) mengatakan, sumber data utama dalam penelitian analisis deskriptif kualitatif adalah kata-kata dan tindakan, selebihnya adalah data tambahan seperti dokumen-dokumen dan lain-lain.Penelitian ini menggunakan data primer dan data sekunder sebagai dasar analisis. Data primer merupakan data yang diperoleh dari hasil kegiatan observasi di lapangan dan hasil focus discussion group (FGD) yang dilakukan dengan nara sumber. Sedangkan data sekunder merupakan data yang penulis peroleh dari Badan Perencanaan Daerah Kota Padang berupa Emonev setiap OPD yang ada di Kota Padang. Adapun teknik pengumpulan data yang penulis pilih dalam melakukan penelitian ini adalah sebagai berikut:

1. Dokumentasi 
Dokumentasi berasal dari kata dokumen, yang berarti barang tertulis, metode dokumentasi berarti cara pengumpulan data dengan mencatat data-data yang sudah ada. Menurut Arikunto (1998:206) metode dokumentasi merupakan mencari data mengenai hal-hal atau variabel yang berupa catatan, transkrip, buku, surat kabar, majalah, prasasti, notulen rapat, lengger, agenda, dan sebagainya. Dibandingkan dengan metode lain, metode ini tidak begitu sulit artinya apabila ada kekeliruan sumber datanya masih tetap atau tidak berubah.

2. Focus Group Discussion (FGD)

Menurut Paramita dan Kristiana (2013) Focus Group Discussion (FGD) adalah bentuk diskusi yang didesain untuk memunculkan informasi mengenai keinginan, kebutuhan, sudut pandang, kepercayaan dan pengalaman yang dikehendaki peserta. FGD bertujuan untuk mengumpulkan data mengenai persepsi dan pandangan peserta terhadap sesuatu, tidak berusaha mencari consensus atau mengambil keputusan mengenai tindakan apa yang akan diambil. Dalam FGD ini topic diskusi ditentukan terlebih dahulu dan diatur secara berurutan sehingga FGD dapat berjalan dengan lancar sehingga memudahkan dalam pengambilan keputusan. Dalam penelitian analisis perencanaan dan evaluasi penganggaran kota Padang ini dilakukan FGD untuk mendapatkan kesepakatan bersama dalam memecahkan topik perencanaan dan pengevaluasian.

FGD yang dilakukan berupa Musyawarah Perencanaan Pembangunan (Musrenbang) dan Forum Organisasi Perangkat Daerah (OPD). Musrenbang merupakan forum antar pemangku kepentingan dalam rangka menyusun rencana pembangunan daerah. Dalam kegiatan Musrenbang pihak-pihak yang diundang adalah seluruh OPD yang ada dilingkungan pemerintah daerah kota Padang, organisasi-organisasi yang ada di kota Padang, dan tokoh-tokoh masyarakat selain itu Musrenbang juga diikuti oleh anggota DPRD. Tujuan diadakan Musrenbang adalah untuk membahas rancangan RPJPD dalam rangka penajaman, penyelarasan, klarifikasi dan kesepakatan terhadap visi, misi, arah kebijakan dan sasaran pokok RPJPD. Sedangkan forum OPD merupakan forum yang dilakukan oleh seluruh anggota OPD dilingkungan pemerintah daerah khususnya kota Padang untuk merumuskan program dan kegiatan sesuai dengan tugas dan fungsi Perangkat Daerah provinsi dan kabupaten/kota.

\section{METODE ANALISIS DATA}

Analisis data dilakukan dengan menggunakan metode analisis deskriptif yang pada dasarnya menggambarkan hasil olahan data yang telah terkumpul sebagaimana adanya dengan penjelasan-penjelasan yang memadai tanpa bermaksud membuat kesimpulan yang berlaku untuk umum atau generalisasi.

Adapun analisis data yang akan penulis gunakan merujuk kepada pendekatan yang di cantumkan dalam Nordiawan (2006), diantaranya:

1. Penetapan strategi organisasi (visi, misi, dan tujuan)

Pengukuran terhadap strategi organisasi dilihat dari adanya visi, misi, dan tujuan yang ditetapkan oleh pemerintah daerah. Selain itu untuk melihat adanya penetapan strategi organisasi terdapat hubungan antara misi, tujuan dan sasaran yang ingin dicapai oleh pemerintah daerah.

2. Pentapan aktifitas

Penetapan aktifitas terkait anggaran berbasis kinerja dengan konsep money follow program dilakukan dengan melihat penetapan program prioritas daerah. 
3. Evaluasi dan pengambilan keputusan

Evaluasi dan pengambilan keputusan dilakukan dengan mengukur hasil capaian kinerja prioritas daerah dan memberikan peringkat atas capaian yang dihasilkan. Adapun untuk mengukur hasil capaian kinerja prioritas daerah dapat menggunakan rumus:

Tingkat Capaian Kinerja $=\frac{\text { Realisasi Capaian Kinerja }}{\text { Target } \text { hinerja }} X 100 \%$

Sedangkan untuk indikator peringkat capaian kinerja dapat dinilai menggunakan ketentuan berikut ini:

Tabel 2. Interval Nilai dan Kriteria Penilaian Realisasi Kinerja

\begin{tabular}{|l|l|l|}
\hline No. & $\begin{array}{l}\text { Interval Nilai Realisasi } \\
\text { Kinerja }\end{array}$ & $\begin{array}{l}\text { Kriteria Penilaian } \\
\text { Realisasi Kinerja }\end{array}$ \\
\hline 1 & $91 \% \leq 100 \%$ & Sangat Tinggi \\
\hline 2 & $76 \% \leq 90 \%$ & Tinggi \\
\hline 3 & $66 \% \leq 75 \%$ & Sedang \\
\hline 4 & $51 \% \leq 65 \%$ & Rendah \\
\hline 5 & $\leq 50 \%$ & Sangat Rendah \\
\hline \multicolumn{2}{l}{ Sumber: E-monev SKPD }
\end{tabular}

\section{PEMBAHASAN}

Penerapan Anggaran Berbasis Kinerja dengan Konsep Money Follow Program

Dalam hal ini penerapan anggaran berbasis kinerja dinilai dengan menggunakan kriteria yang dicantumkan dalam buku Nordiawan (2006) yaitu dengan melihat adanya penetapan strategi organisasi (terkait visi, misi, tujuan, dan sasaran), penetapan aktifitas, dan evaluasi serta pengambilan keputusan.

\section{Penetapan Strategi Organisasi}

Dalam hal ini Kota Padang sudah melakukan penetapan strategi organisasi yang tergambar dari adanya visi, misi, tujuan, dan sasaran. Karena hal terpenting dalam rumusan kebijakan pembangunan adalah kejelasan mengenai apa yang akan diwujudkan dalam lima tahun mendatang (impact) berdasarkan analisis kinerja pembangunan saat ini, serta permasalahan dan isu strategis pembangunan daerah yang akan ditangani selama lima tahun ke depan. Visi merupakan rumusan umum mengenai keadaan yang diinginkan pada akhir periode perencanaan, sedangkan misi merupakan rumusan umum mengenai upaya-upaya yang akan dilaksanakan untuk mewujudkan visi. Adapun visi Kota Padang adalah "terwujudnya Kota Padang sebagai kota pendidikan, perdagangan, dan pariwisata yang sejahtera, religius, dan berbudaya". Sedangkan misi, tujuan, da sasaran dapat dilihat pada table berikut ini: 
Tabel 3. Hubungan Misi, Tujuan Dan Sasaran

\begin{tabular}{|c|c|c|}
\hline Misi & Tujuan & Sasaran \\
\hline $\begin{array}{l}\text { Misi 1: } \\
\text { Mewujudkan pendidikan yang } \\
\text { berkualitas untuk menghasilkan } \\
\text { sumber daya manusia yang } \\
\text { beriman, kreatif, dan berdaya } \\
\text { saing. }\end{array}$ & $\begin{array}{l}\text { 1. Mewujudkan } \\
\text { kualitas sumber } \\
\text { daya manusia } \\
\text { yang beriman, } \\
\text { kreatif, dan } \\
\text { berdaya saing } \\
\text { tinggi. }\end{array}$ & $\begin{array}{ll}\text { 1. } & \text { Mewujudkan peningkatan } \\
\text { kualitas pendidikan } \\
\text { 2. }\end{array}$ \\
\hline $\begin{array}{l}\text { Misi 2: } \\
\text { Menjadikan Kota Padang pusat } \\
\text { perdagangan wilayah Sumatera } \\
\text { Barat. }\end{array}$ & $\begin{array}{l}\text { 1. } \text { Mewujudkan Kota } \\
\text { Padang sebagai } \\
\text { pusat kegiatan } \\
\text { perdagangan } \\
\text { untuk wilayah } \\
\text { pantai barat } \\
\text { sumatera }\end{array}$ & $\begin{array}{l}\text { 1. Terciptanya peningkatan volume } \\
\text { transaksi perdagangan dan jasa. } \\
\text { 2. Terciptanya peningkatan kontribusi } \\
\text { sector perdagangan dalam } \\
\text { perekonomian Kota Padang. }\end{array}$ \\
\hline & $\begin{array}{ll}\text { 1. } & \text { Mewujudkan Kota } \\
& \text { Padang sebagai pusat } \\
& \text { Pertumbuhan Ekonomi }\end{array}$ & 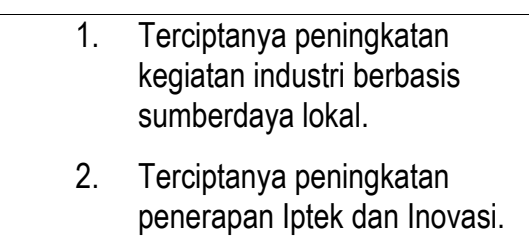 \\
\hline $\begin{array}{l}\text { Misi 3: } \\
\text { Menjadikan Kota Padang sebagai } \\
\text { daerah tujuan wisata yang } \\
\text { nyaman dan berkesan. }\end{array}$ & $\begin{array}{l}\text { 1. Mewujudkan Kota } \\
\text { Padang sebagai } \\
\text { daerah tujuan } \\
\text { wisata yang } \\
\text { nyaman dan } \\
\text { berkesan }\end{array}$ & $\begin{array}{l}\text { 1. Tercapainya peningkatan rata-rata } \\
\text { lama tinggal wisata di Kota Padang. } \\
\text { 2. Tercapainya peningkatan jumlah } \\
\text { kunjungan wisata nusantara dan } \\
\text { mancanegara. } \\
\text { 3. Tercapainya kondisi wisata yang } \\
\text { nyaman dan berkesan. }\end{array}$ \\
\hline $\begin{array}{l}\text { Misi 4: } \\
\text { Meningkatkan kesejahteraan } \\
\text { masyarakat dan pengembangan } \\
\text { ekonomi kerakyatan. }\end{array}$ & $\begin{array}{l}\text { 1. } \begin{array}{l}\text { Meningkatkan } \\
\text { kesejahteraan } \\
\text { masyarakat }\end{array}\end{array}$ & $\begin{array}{ll}\text { 1. } & \text { Tercapinya peningkatan } \\
\text { kualitas ekonomi masyarakat. } \\
\text { 2. Berkurangnya tingkat } \\
\text { kemiskinan. } \\
\text { 3. Tercapainya peningkatan } \\
\text { kualitas kesehatan } \\
\text { masyarakat. }\end{array}$ \\
\hline
\end{tabular}




\begin{tabular}{|c|c|c|}
\hline Misi & Tujuan & Sasaran \\
\hline & $\begin{array}{ll}\text { 2. } & \text { Mewujudkan } \\
\text { ekonomi } \\
\text { kerakyatan yang } \\
\text { tangguh }\end{array}$ & $\begin{array}{l}\text { 1. Tercapainya peningkatan } \\
\text { penyediaan lapangan kerja } \\
\text { dan usaha. } \\
\text { 2. Tercapainya peningkatan } \\
\text { kekuatan ekonomi kerakyatan. }\end{array}$ \\
\hline \multirow[t]{6}{*}{$\begin{array}{l}\text { Misi 5: } \\
\text { Menciptakan Kota Padang yang } \\
\text { aman, bersih, tertib, bersahabat, } \\
\text { dan menghargai kearifan lokal. }\end{array}$} & $\begin{array}{l}\text { Mewujudkan Kota } \\
\text { Padang yang } \\
\text { aman dan tanggap } \\
\text { bencana. }\end{array}$ & $\begin{array}{l}\text { 1. Tersedianya informasi tentang } \\
\text { Daerah Rawan Bencana. } \\
\text { 2. Tercapainya peningkatan } \\
\text { sarana prasarana } \\
\text { penanggulangan bencana. } \\
\text { 3. Tercapainya peningakatan } \\
\text { kesiapsiagaan warga kota } \\
\text { mengantisipasi } \\
\text { penanggulangan bencana. }\end{array}$ \\
\hline & $\begin{array}{l}\text { Mewujudkan } \\
\text { lingkungan hidup } \\
\text { kota yang } \\
\text { berkualitas }\end{array}$ & $\begin{array}{l}\text { 1. Tercapainya peningkatan } \\
\text { kualitas lingkungan hidup. } \\
\text { 2. Tercapainya peningkatan } \\
\text { konservasi, rehabilitasi, dan } \\
\text { pemulihan ekosistem. } \\
\text { 3. Tercapainya penurunan } \\
\text { tingkat pencemaran udara dan } \\
\text { air. }\end{array}$ \\
\hline & $\begin{array}{l}\text { Mewujudkan } \\
\text { infrastruktur yang } \\
\text { ramah dan aman }\end{array}$ & 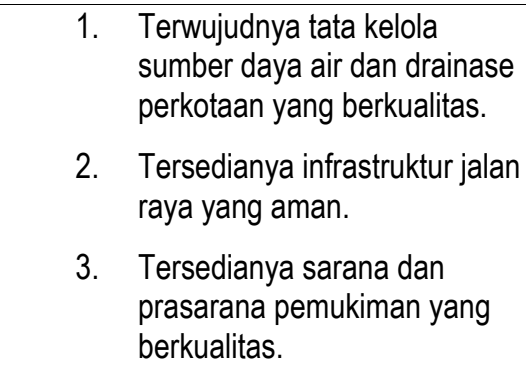 \\
\hline & $\begin{array}{l}\text { 4. Mewujudkan Kota } \\
\text { Padang yang } \\
\text { bersih dan indah }\end{array}$ & $\begin{array}{l}\text { 1. } \begin{array}{l}\text { Terciptanya peningkatan } \\
\text { system pengelolaan } \\
\text { persampahan. }\end{array} \\
\text { 2. Terciptanya peningkatan } \\
\text { kualitas dan kuantitas Ruang } \\
\text { Terbuka Hijau, Hutan Kota, } \\
\text { Taman Kota, dan TPU. }\end{array}$ \\
\hline & $\begin{array}{l}\text { 5. Mewujudkan } \\
\text { transportasi } \\
\text { perkotaan yang } \\
\text { lancar, aman, } \\
\text { nyaman, dan } \\
\text { murah. }\end{array}$ & $\begin{array}{l}\text { 1. Tersedianya pelayanan jasa } \\
\text { angkutan kota yang cukup dan } \\
\text { lancar keseluruh wilayah kota. } \\
\text { 2. Terciptanya peningkatan } \\
\text { keamanan dan keselamatan } \\
\text { lalu lintas. }\end{array}$ \\
\hline & $\begin{array}{l}\text { 6. } \\
\text { pewujudkan } \\
\text { benataan ruang, } \\
\text { pangunan dan } \\
\text { perumahan yang } \\
\text { serasi, selaras, }\end{array}$ & $\begin{array}{l}\text { 1. Terlaksananya penataan } \\
\text { bangunan dan perumahan } \\
\text { sesuai dengan Rencana Tata } \\
\text { Ruang Kota. }\end{array}$ \\
\hline
\end{tabular}




\begin{tabular}{|c|c|c|}
\hline Misi & Tujuan & Sasaran \\
\hline & dan seimbang. & \\
\hline & $\begin{array}{l}\text { 7. } \text { Mewujudkan } \\
\text { penyediaan lahan } \\
\text { untuk kebutuhan } \\
\text { pembangunan } \\
\text { kota yang } \\
\text { berkeadilan. }\end{array}$ & $\begin{array}{l}\text { 1. Tersedianya lahan untuk } \\
\text { kebutuhan pembangunan kota } \\
\text { yang sesuai peruntukannya. }\end{array}$ \\
\hline \multirow[t]{3}{*}{$\begin{array}{l}\text { Misi 6: } \\
\text { Mewujudkan tata kelola } \\
\text { pemerintahan yang baik, bersih, } \\
\text { dan melayani. }\end{array}$} & $\begin{array}{l}\text { 1. Mewujudkan tata } \\
\text { kelola pemerintah } \\
\text { yang baik. }\end{array}$ & $\begin{array}{l}\text { 1. Tercapainya peningkatan } \\
\text { Perencanaan Pembangunan } \\
\text { daerah dan Pengelolan Data } \\
\text { 2. Tercapainya peningkatan } \\
\text { Akuntabilitas Kinerja Birokrasi. }\end{array}$ \\
\hline & $\begin{array}{l}\text { 2. Mewujudkan Tata Kelola } \\
\text { Pemerintahan yang bersih. }\end{array}$ & $\begin{array}{l}\text { 1. Tercapainya pengurangan } \\
\text { tindak Korupsi, Kolusi, dan } \\
\text { Nepotisme (KKN) dilingkungan } \\
\text { birokrasi. }\end{array}$ \\
\hline & $\begin{array}{l}\text { 3. Mewujudkan Tata } \\
\text { kelola } \\
\text { pemerintahan } \\
\text { yang melayani }\end{array}$ & $\begin{array}{l}\text { 1. Terwujudnya pelayanan public } \\
\text { yang berkualitas (prima). }\end{array}$ \\
\hline
\end{tabular}

\section{Penetapan Aktivitas}

Pemerintah Kota Padang sudah melakukan penetapan terhadap aktifitas priotitas daerahnya. Dalam penetapan anggaran berbasis kinerja dengan konsep money follow program maka sangat diperlukan adanya penetapan aktifitas yang akan dilakukan. Aktifitas tersebut menyangkut dengan aktifitas prioritas daerah dan aktifitas lain selain prioritas daerah. Adapun aktifitas yang ditetapkan oleh Pemerintah Kota Padang adalah sebagai berikut:

a. Percepatan Pembangunan Sarana Perdagangan Kota dan Sentra Ekonomi

b. Peningkatan dan Pemerataan Mutu Pendidikan

c. Peningkatan Infrastruktur/sarana Prasarana Perkotaan, Transportasi Kota, Kerjasama Regional dan Internasional

d. Pengembangan Industri Pariwisata dan Kelautan serta Pemberdayaan Masyarakat Pesisir dalam Mendorong Pertumbuhan Ekonomi Kreatif yang Berdaya Saing

e. Peningkatan Penataan Ruang dan Peningkatan Pembangunan Kawasan Perumahan Pemukiman Perkotaan

f. Peningkatan dan Pemerataan Akses dan Kualitas Pelayanan Kesehatan Masyarakat

g. Pembangunan Ekonomi Berbasis Masyarakat dan Mendorong Tumbuhnya Investasu Daerah Dalam Rangka Peningkatan Kesejahteraan Masyarakat dan Penurunan Tingkat Kemiskinan

h. Penataan Lingkungan Perkotaan Yang Hijau, Berkelanjutan, dan Berbasis Mitigasi Bencana

i. Peningkatan Penataan Birokrasi dan Tata Kelola Penyelenggaraan Pemerintahan yang Baik dan Bersih untuk Peningkatan Pelayanan Publik

j. Pengamalan Agama dalam Kehidupan Masyarakat yang Berbudaya 


\section{Evaluasi dan Pengambilan Keputusan}

Pemerintah Kota Padang telah melakukan evaluasi terhadap kinerja program prioritas, dimana hasil evaluasi dari setiap program prioritas adalah sebagai berikut:

\section{a. Percepatan Pembangunan Sarana Perdagangan Kota Dan Sentra Ekonomi}

Untuk mendukung prioritas daerah melakukan percepatan pembangunan sarana perdagangan kota dan sentra ekonomi, pemerintah daerah Kota Padang telah mengalokasikan anggaran untuk 7 program yaitu:

a) Program perlindungan konsumen dan pengamanan perdagangan

b) Program peningkatan efisiensi perdagangan dalam negeri

c) Program pembinaan pedagang kaki lima dan asongan

d) Program kelengkapan Sarana dan prasarana pasar

e) Program sarana dan prasarana kebersihan pasar

f) Program pengembangan dan perluasan pangsa pasar

g) Program pengendalian ketersediaan, stabilisasi harga dan distribusi barang kebutuhan pokok dan barang penting

Tingkat capaian kinerja untuk ketujuh program ini secara fisik adalah 100\% sedangkan capaian kinerja anggaran mencapai 98.36\% dengan predikat kinerja sangat tinggi.

\section{b. Peningkatan dan Pemerataan Mutu Pendidikan}

Prioritas daerah kota Padang yang kedua adalah peningkatan dan pemerataan mutu pendidikan dengan sasaran prioritas meningkatkan dan meratanya mutu pendidikan. Untuk mencapai sasaran ini, telah dianggarkan 18 program, dimana kondisi sampai dengan akhir triwulan IV tahun 2017 menunjukkan secara rata-rata tingkat capaian kinerja fisik adalah 98.82\% (sangat tinggi) dan tingkat capaian kinerja keuangan adalah $89.08 \%$ (tinggi). Program pendidikan politik masyarakat yang dilakukan oleh dinas pemuda dan olah raga merupakan program dengan tingkat capaian kinerja keuangan yang paling rendah yaitu $41.88 \%$ (capaian kinerja sangat rendah). Tingkat capaian kinerja kurang dari $90 \%$ juga terjadi pada program peningkatan dan penegmbangan pengelolaan keuangan daerah pada dinas pemuda dan olah raga. Terdapat 2 kegiatan terkait dengan program ini yaitu pengelolaan, pengendalian dan pengawasan retribusi (realisasi keuangan 74.06\%) dan monitoring validasi data asset (tingkat capaian 87.36\%). Kondisi ini antara lain disebabkan oleh kurangnya tenaga sumber daya manusia untuk mengisi jabatan fungsional pada OPD Dinas pemuda dan olahraga.

\section{c. Peningkatan Infrastruktur/sarana prasarana perkotaan, transportasi, kota, kerjasama regional dan internasional}

Hasil evaluasi sampai akhir triwulan IV menunjukkan secara rata-rata tingkat capaian kinerja fisik mencapai $98.42 \%$ (sangat tinggi) dan capaian kinerja keuangan $86.12 \%$ (tinggi). Program dengan tingkat capaian kinerja fisik paling rendah adalah program penyelesaian konflik-konflik pertanahan (78\%). Sedangkan program dengan tingkat capaian kinerja keuangan paling rendah adalah program penataan penugasan, pemilikan, penggunaan dan pemanfaatan tanah (27.53\%). Kedua program ini berada dibawah tanggungjawab DPRKPP. Terkait program penataan penugasan pemilikan, penggunaan dan pemanfaatan tanah yang rendah capaiannya disebabkan oleh adanya pencanangan program PTSL (pendaftaran Tanah Sistematis Lengkap) dari pemerintah pusat dengan dana APBNP sehingga biaya sertifikat sudah digratiskan. 
Hal ini menyebabkan kegiatan pemberian sertifikat tanah hak pakai kepada masyarakat tingkat capaian kinerja keuangannya rendah.

\section{d. Pengembangan Industri Pariwisata dan Kelautan serta Pemberdayaan Masyarakat Pesisir dalam Mendorong Pertumbuhan Ekonomi Kreatif yang Berdaya Saing}

Untuk mencapai sasaran prioritas daerah ini didukung oleh 10 program, dimana hasil evaluasi capaian kinerja sampai akhir triwulan IV menunjukkan seluruh program sudah mencapai realisasi fisik 100\% kecuali untuk program peningkatan kegiatan budaya kelautan dan wawasan maritime kepada masyarakat (79.06\%). Program ini berada dibawah lingkup tugas Dinas Perikanan dan Kelautan dengan kegiatan peringatan hari nusantasra dan pemilihan putra/putri bahari.

\section{e. Peningkatan penataan Ruang dan Peningkatan Pembangunan Kawasan Perumahan Pemukiman Perkotaan}

Meningkatnya penataan ruang dan peningkatan pembangunan kawasan perumahan pemukiman perkotaan merupakan sasaran prioritas pembangunan yang kelima dari pemerintah Kota Padang. Terdapat 12 program yang dilaksanakan untuk mencapai sasaran prioritas ini. Dimana hasil evaluasi menunjukkan bahwa secara kinerja fisik semua program telah terealisasi $100 \%$ kecuali untuk program perencanaan tata ruang (83.87\%). Namun secara kinerja keuangan tingkat capaian kinerja hanya mencapai $80.37 \%$ (tinggi). Terdapat 4 OPD yang bertanggungjawab untuk mewujudkan prioritas daerah ini yaitu Dinas PUPR, Dinas Lingkungan Hidup dan Kebersihan, DPRKPP dan BAPPEDA. Program dengan capaian kinerja keuangan rendah terjadi pada 3 program yaitu program lingkungan sehat perumahan, program pemberdayaan komunitas perumahan dan program pengelolaan areal pemakaman.

\section{f. Peningkatan dan Pemerataan Akses dan Kualitas Layanan Kesehatan Masyarakat}

Untuk mencapai sasaran meningkat dan meratanya akses dan kualitas layanan kesehatan masyarakat telah dilaksanakan 23 program secara kolaboratif oleh RSUD dan Dinas Kesehatan. Hasil evaluasi menunjukkan secara rata-rata tingkat capaian kinerja fisik mencapai 97.89\% (sangat tinggi) dan capaian kinerja keuangan $82.94 \%$ (tinggi). Realisasi keuangan yang rendah juga terjadi pada kegiatan penyediaan PMT bagi balita gizi buruk dan ibu hamil KEK (31.15\%).

\section{g. Pembangunan Ekonomi Berbasis Masyarakat dan Mendorong Tumbuhnya Investasi Daerah dalam rangka Peningkatan Kesejahteraan Masyarakat dan Penurunan Tingkat Kemiskinan}

Untuk mencapai sasaran prioritas daerah ini dilakukan 43 program. Dimana hasil evaluasi menunjukkan bahwa tingkat capaian kinerja fisik secara rata-rata mencapai 99.99\% dan realisasi keuangan mencapai 95.06\%. 


\section{h. Penataan Lingkungan Perkotaan yang Hijau, Berkelanjutan dan Berbasis Mitigasi Bencana}

Untuk mencapai sasaran prioritas pembangunan daerah ini telah dilaksanakan 14 program. Hasil evaluasi sampai akhir triwulan IV menunjukkan realisasi fisik seluruh kegiatan telah mencapai $100 \%$. Namun realisasi keuangan hanya mencapai $87.43 \%$.

\section{i. Peningkatan Penataan Birokrasi dan Tata Kelola Penyelenggaraan Pemerintahan yang Baik dan Bersih untuk Peningkatan Pelayanan Publik}

Untuk mencapai sasaran prioritas ini telah dilaksanakan 45 program. Secara rata-rata seluruh program telah tercapai $100 \%$ kinerja fisiknya, namun realisasi keuangan masih terdapat realisasi 49,78\% yaitu untuk program peningkatan pemberantasan penyakit masyarakat (PEKAT) pada Dinas Kesatuan Bangsa dan Politik (Kesbangpol).

\section{j. Pengamalan Agama dalam Kehidupan Masyarakat yang Berbudaya}

Untuk mencapai sasaran meningkatnya pengamalan agama dalam kehidupan masyarakat yang berbudaya telah dilakukan 8 program. Secara rata-rata seluruh program telah tercapai $100 \%$ kinerja fisiknya, namun realisasi keuangan masih terdapat realisasi $65.35 \%$ yaitu untuk program pendidikan politik masyarakat yang dilakukan oleh OPD Dispora. Kondisi ini disebabkan karena keterbatasan jumlah ASN fungsional pada Dispora.

\section{KESIMPULAN DAN SARAN}

Penelitian ini menemukan bahwa anggaran berbasis kinerja dengan konsep money follow program telah diterapkan di Kota Padang. Hal ini terlihat dengan adanya penetapan strategi organisasi dan aktifitas yang didasarkan pada visi dan misi pemerintah Kota Padang. Selain itu penelitian ini juga menemukan bahwa hasil evaluasi telah digunakan sebagai dasar dalam pengambilan keputusan dan perencanaan untuk tahun berikutnya.

Penelitian ini dapat memberikan masukan bagi Pemerintah Kota Padang dengan memberikan bukti bahwa penerapan anggaran berbasis kinerja dengan konsep money follow program yang dilaksanakan secara konsisten dapat bermanfaat untuk tahapan perencanaan dan penganggaran pemerintah daerah. penelitian ini hanya mengukur ketercapaian persentase capaian kinerja dari sisi fisik dan keuangan secara deskriptif. Namun penelitian ini belum menganalisis efektifitas pelaksanaan kegiatan. Oleh karena itu penelitian selanjutnya disarankan untuk menganalisis tingkat efektifitas kinerja pemerintah daerah. 


\section{REFERENSI}

(1) Bastian, I. (2016). Strategi Manajemen Sektor Publik. Jakarta: Salemba Empat

(2) Bastian, I. (2006). Sistem Perencanaan dan Penganggaran Pemerintah Daerah di Indonesia. Jakarta. Salemba Empat.

(3) Kontan. (2016). "Pemerintah Gunakan Money Follow Program" (http://nasional.kontan.co.id/news/pemerintah-gunakan-money-followprogram akses tanggal 13 Agustus 2018. 1:20)

(4) Majalah Keuangan Publik. (2016). Warta Anggaran Edisi 30. (http://www.anggaran.depkeu.go.id/Content/Publikasi/Warta\%20Anggaran\% 2030.pdf akses 03 Agustus 2018. 16:36)

(5) Nanda, R. Darwanis. (2016). Analisis Implementasi Anggaran Berbasis Kinerja Pada Pemerintah Daerah (Studi Deskriptif Pada Dinas DPKKD Kabupaten Aceh Selatan) Jurnal Ilmiah Mahasiswa Ekonomi Akuntansi (JIMEKA) Vol. 1. No. 1

(6) Nordiawan, D. (2006). Akuntansi sektor publik. Jakarta. Salemba Empat

(7) Peraturan Menteri Dalam Negeri No. 86 Tahun 2017 Tentang Tata Cara Perencanaan, Pengendalian dan Evaluasi Pembangunan Daerah, Tata Cara Evaluasi Rancangan Peraturan Daerah Tentang Rencana Pembangunan Jangka Panjang Daerah dan Rencana Pembangunan Jangka Menengah Daerah, serta Tata Cara Perubahan Rencana Pembangunan Jangka Panjang Daerah, Rencana Pembangunan Jangka Menengah Daerah, dan Rencana Kerja Pemerintah Daerah

(8) Undang-Undang Republik Indonesia Nomor 23 Tahun 2014 Tentang Pemerintah Daerah

(9) Undang-Undang Republik Indonesia Nomor 58 Tahun 2005 Tentang Pengelolaan Keuangan Daerah

(10) Undang-Undang Republik Indonesia Nomor 25 Tahun 2004 Tentang Sistem Perencanaan Pembangunan Nasional 